International Journal of Linguistics, Literature and Translation

ISSN: 2617-0299 (Online); ISSN: 2708-0099 (Print)

DOI: 10.32996/ijltt

Journal Homepage: www.al-kindipublisher.com/index.php/ijllt

IJLLT

\title{
Teachers and Students' Attitudes towards the Integration of the Target Culture in the English as a Foreign Language Class: A Case Study
}

\author{
Simon Pierre DABOU 1 (D), Abdelhak HAMMOUDI ${ }^{2}$ (D) $\triangle$ and Romaissa CHIBANI ${ }^{3}$ (D) \\ ${ }^{1}$ English Instructor, Yacouba Traoré de San High School, Mali, Algeria \\ ${ }^{23}$ Associate professor, Research Laboratory of Language Didactics, ENS Sétif, Algeria \\ $\triangle$ Corresponding Author: Abdelhak HAMMOUDI, E-mail: a.hammoudi@ens-setif.dz
}

ARTICLE INFORMATION

Received: March 04, 2021

Accepted: April 20, 2021

Volume: 4

Issue: 4

DOI: $10.32996 /$ ijllt.2021.4.4.28

\section{KEYWORDS}

Target culture, attitudes towards culture, EFL, values, human cultural rights

\section{ABSTRACT}

Language and culture are like two sides of the same coin, the music on a radio or the soul in a body. The two are so interrelated that separating them is almost impossible. Therefore, teaching a foreign language implies integrating the target culture. In this context, this study aimed to investigate teachers and students' attitudes towards the integration of the English culture in the EFL curriculum at the University of Sétif 2. A Semi-structured interview with six English language teachers and a questionnaire to 53 third-year English students were the tools used to collect the necessary data. The analysis of the data showed that all the teachers were for the integration of the target culture in the EFL classes. The study also revealed that students who had positive attitudes towards the target culture represented only $28 \%$ of the sample. Therefore, the researchers suggested that the concept of target culture be properly defined within the EFL class and appropriately approached to sustain interest. Moreover, teachers are encouraged to integrate certain aspects of the target culture, such as language, norms, and values, to avoid misunderstanding, and respect each other's cultural rights.

\section{Introduction}

The studies of attitude have a historical background (Oppenheim, 1998). Schools of interpretations have offered various definitions. The behaviourists approached it as a social, therefore observable product (Jabeen\& Shah, 2011). For the mentalists, attitude is based on cognitive aspects that can only be analysed on the basis of learners' report about their mental response to particular circumstances (Fasold, 1985). Cambridge Advanced Learner's Dictionary Edition 3, 2008 (CALD3 hereafter) defines it as a feeling or opinion about someone or something, or a way of behaving that is caused by this. This definition covers three dimensions: emotional, cognitive and behavioural, all of which refer to the individual's response to concrete entities or abstract concepts.

Culture is, among other things, the core of language and it does correlate with attitude. In this respect, Paige et al. (2003) define culture in terms of negative or positive attitude. In other words, culture is how people respond, whether positively or natively, to a society' values and behaviours. Hinkel (1999) classifies culture in terms of forms of speech acts, social organisations, notions of personal space and appropriate gesture. Kramsch (2008) considers it as "membership in discourse community". Cambridge Advanced Learner's Dictionary (CALD) defines culture as "the way of life, especially the general customs and beliefs of a particular group of people at a particular time". Brooks (1975) believes it is the core of a society because it connects people through identity and shapes the way they live, behave, speak and interact. Language cannot be separated from the culture of the people who use it because through culture, we can understand why some people speak and interact in a particular way, and under certain circumstances which would not mean the same for other people or would signify nothing at all. Equally, the language used by a society is by far the best language to explain the culture of this society. Thus, Brown (2000, p.77) wrote "language is a part of culture, and culture is a part of language".

\begin{tabular}{ll|l|l}
$\mathbf{K}$ & $\mathbf{C}$ & AL-KINDI CENTER \\
$\mathbf{R}$ & $\mathbf{D}$ & FOR RESEARCH AN
\end{tabular}

$\mathbf{R}$ D DEVELOPMENT

Your gateway to world-class research

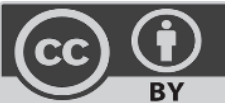

Published by Al-Kindi Center for Research and Development, London, United Kingdom. Copyright (c) the author(s). This open access article is distributed under a Creative Commons Attribution (CC-BY) 4.0 license 
However, the target culture teaching has not been easily accepted in some countries due to religion (Jabeen \& Shah, 2011). In these societies, some people think that target culture teaching may harm the mother culture and students' way of thinking. Hence, students should focus only on the local culture as the main source for cultural content ( Eslami \& Chen , 2012). In a study conducted on Pakistani University students' attitudes towards the target culture teaching, Jabeen \& Shah (ibid) found that due to the local religion, the respondents showed a negative attitude towards the teaching of the Target culture. Nadia (2015) made a similar study at Biskra University and found that the students showed negative attitudes towards the integration of the target culture in the EFL class. She added that students living in Biskra, like all the southern regions, are guided by religious imperatives which are part of their daily behaviour,

\subsection{Statement of the Problem}

According to the Algerian National Commission of Programs (2006), the goal of English language teaching in Algeria is to help the societymove to modernity by sharing and exchanging scientific, cultural and civilizational ideas with the target language community. Knowing the target culture contributes to the knowledge of the self and the other. With this knowledge in mind, the Algerian teachers and students should welcome the opportunity to enjoy diversity and universality. Unfortunately, the cultural clash and cultural shock tremendously hinder the possibility to learn English properly. This culture shock results in students taking their distance and gradually developing negative attitudes towards the target culture. Raising students' awareness about the differences between cultures and bringing them to analytical reasoning will doubtlessly make inter-culturally competent speakers.

\subsection{Aim of the Study}

This study aimed at investigating the attitudes (perceptions, feelings and opinions) of both teachers and students towards the target language culture integration in English teaching curriculum and check whether the integration of the target culture in the EFL class constitutes a threat or benefit to the teaching of the English language.

\subsection{Research Questions}

The questions we try to answer in this research article include:

1. What are teachers and students' attitudes towards the integration of the target culture in the EFL class?

2. How does religion affect students' attitudes towards the target culture?

3. To what extent have Algerian teachers integrated the target culture in the EFL curriculum?

\section{Literature Review}

\subsection{Nelson Brooks' Notion of Culture}

The primary element that identifies culture is the omnipresence of the individual. Brooks (1968) believes that: "the most important single criterion in distinguishing culture from geography, history, folklore, sociology, literature, and civilization is the fact that in culture we never lose sight of the individual". In an attempt to define culture, Brooks established a list of separate meanings related to culture. However, he emphasized the fourth item he believed the majority of people grasp the least.

- Culture1 means biological growth.

- Culture 2 means personal refinement.

- Culture 3 means literature and the fine arts.

- Culture 4 means patterns for living.

- Culture 5 means the sum total of a way of life.

- Culture 4 refers to the role a person plays in the different kinds of life situations and the models for attitude and conduct they involve. Actually, these models make every human being justify the world to himself, associate it with his community, and relate to the social order to which he is attached. This quotation underlines the role of the individual in the community not just as the person he or she represents but as how he or she relates to the society, the beliefs and the environment until he or she is part of the community. In other terms, it is learning to become part of a society by observing the patterns for living.

\subsection{The Concept of Culture Learning}

The notion of Brooks' culture was unsurprisingly criticized by Paige et al. (2003) mainly because he focused only on surface-level behavior and thus neglected the value orientation, the variability of behavior, and the participative role of the individual to create meaning through interacting with others. They proposed a new perspective according to which culture is dynamic within the community members, which renders the possibility for constructing meaning through interaction. Thus, language plays not only the role of a medium but the role of a shaper of culture as well. Therefore, the purpose behind learning culture moves from cultural facts memorization to acquiring interactional competence. The latter refers to the student becoming an effective language and culture learner. More importantly, when culture is put at the heart of language, students become culture learners. Moreover, to achieve this goal, Paige et al.(idem) emphasized that "students must develop a variety of learning strategies 
ranging from reflective observation to active experimentation or what Kolb refers to as 'experiential learning' style". In other terms, culture learning is dynamic and is dependent upon context that students should find ways to approach it and not referring only to facts and norms.

\subsection{Themes of Culture}

The division of culture in themes is generally made at two levels: Big C culture and Small c culture. The original coinage came from Brooks (1968) who suggests his "surface culture" vs. "deep culture" later developed as Big C and little c (Thu, 2010).

Referring to small c, authors explain that it includes habitual aspects embedding the whole of life. Peterson (2004) defines small c as the small or common side of culture that includes themes like value, clothing, food or eating habit, gestures, lifestyle, beliefs etc. If big $\mathrm{C}$ culture is reserved for the educated or professional, small $\mathrm{c}$ is no least important for it digs into the heart of the community through which one can gain genuine knowledge from the behaviour, thought and way of life of that community. If there is a pragmatic failure, here is the source to explaining what, how and why (Thomas 1982). Because it entails that actual norm, values and beliefs appropriately used are the director of intercultural community success.

\subsection{Sources of Culture}

The importance of culture in teaching materials has an impact on the learning of a language especially a foreign language. Cortazzi and Jin offered (1999) a classification of the sources of culture to see their usability in language textbooks. The first is Source Culture, which is the learner's own culture, is introduced so that EFL learners can have an ample understanding of their own culture (their identity, values etc.) in order to interact with people from various parts of the world about themes of theirs relying on vocabularies from their English background. The second is the Target Culture. Its integration offers the possibility for EFL learners to activate their motivation towards the target language. Alptekin (1993) explains that since it is difficult for native English speaking EFL textbooks writers to source data from other cultures than their own, then they have to rely on the target culture. The third type is International Target Culture which is incorporated in EFL materials to provide an opportunity for nonnative English speakers to choose the cultural norms and practices they want to reflect other than the inner circle Englishes or to skip at least the American and British varieties ( Liu \& Laohawiriyanon, 2013). However, as Andarab (2012) points out it should be made as clear as crystal that the issue at hand is not whether to include culture in the teaching of English or not, but specifically which culture should receive the focus and how to do it. Thu (2010) stressed that the question of whether culture should be taught or not is not valid. In a review of literature, Andarab (2012) is very critical of the way the target culture is being integrated in textbooks. She argues that considering the inseparability of English language and its culture supposes three assumptions: firstly, native speakers not only represent the English language but the owners as well. Secondly, English being the centre of culture in countries where it is spoken as native language and mostly where the dominant culture is English does not necessary mean that these cultures do not differ. Thirdly, the fear that some students may become victims of alienation if they do not want to be culturally assimilated is a point in case. Supporting the view to eradicate the target culture teaching in EFL contexts, Jabeen and Shah (2010), in an analysis of Pakistani students' attitude towards the target culture, found that they were overwhelmingly negative in their responses.. Actually, studies supporting the teaching of the target culture in Muslim countries are increasing at a very fast rate. Some of those studies include Al-Amir, 2017; Aydemir\& Mede, 2014; Bataineh \& Reshidi, 2016; Chalak, 2015; Gonen \& Saglam, 2012;Kahraman, 2016; Sarıçoban \& Çalışan, 2011. All these studies, incidentally conducted in Muslim countries, reported positive responses on the part of the learners. Therefore, the idea to exclude the target culture teaching in Muslim countries due to one or two research papers with negative outcomes is not valid.

\subsection{Types of Culture}

Thumball et al. (2006), as cited in Nadia (2015) proposed a classification of the types of culture divided into individualistic and collectivistic cultures. A detailed presentation of these two types was offered by Govea (2007:06), again cited by Nadia as represented in the table below.

Table 01: Comparing collectivistic and individualistic cultures adopted from Nadia (2015:54)

\begin{tabular}{|c|c|}
\hline Collectivistic Culture & Individualistic Culture \\
\hline $\begin{array}{l}1 \text { The society shows a positive attitude towards } \\
\text { whatever is traditional. } \\
2 \text { Students are expected to learn how to do. } \\
3 \text { The young have to learn while the old do not } \\
\text { accept the role of student. } \\
4 \text { Individual students intervene in class only when } \\
\text { called upon personally by the teacher. } \\
5 \text { Education is a way of gaining prestige in one's } \\
\text { environment. } \\
6 \text { Acquiring a diploma is more important than } \\
\text { acquiring knowledge. }\end{array}$ & $\begin{array}{l}1 \text { The society shows positive attitudes towards whatever is new. } \\
2 \text { There is no age limit to learn "permanent education". } \\
3 \text { Students should learn how to learn. } \\
4 \text { Individual students speak up in class in response to the teacher's } \\
\text { invitation. } \\
5 \text { Education is a way to improving one's economic worth and self- } \\
\text { respect based on ability and confidence. } \\
6 \text { Acquiring competences is more important than acquiring a diploma. }\end{array}$ \\
\hline
\end{tabular}


The table clearly draws a line between individualistic and collectivistic cultures. For the former, education is meant to build competence and knowledge as opposed to the latter, which is for the sake of acquiring a place in society via a diploma.

\subsection{Teachers' Perceptions about Teaching Culture in the EFL Class}

Al-Amir (2017) used a three- Points Likert scale questionnaire to investigate female teachers' perceptions of culture teaching in English as a foreign language classroom at the University of Jeddah. As result, most female teachers supported the teaching of culture in the foreign language class. Likewise, Gonen and Saglam (2012) made an investigation with no reference to gender. Sixty Turkish EFL teachers were asked about their perceptions about the aspects of culture they would integrate into their classes. Both a comprehensive questionnaire and interviews were thus employed. Their findings revealed teachers' awareness to integrate culture in EFL of class. Yeganeh and Raeesi (2014) sought to shed light on the major means of teaching culture and the barriers teachers face when integrating culture in the EFL class. Through a questionnaire, they collected data from 291 teachers from three provinces in Western Iran. The findings showed a gap between the teachers' perceptions and practices in dealing with the target culture. As far as difficulties are concerned, shortage of time was seen as the main obstacle for teaching culture and behavior. Yang and Chen (2016) investigated language instructors' attitudes and beliefs towards teaching culture and the difficulties and barriers of teaching culture to college-level students. The study was conducted using qualitative tools: document miming, classroom observations and interviews with language instructors. Results revealed two profound barriers, namely instructors' beliefs and attitudes in addition to the lack of professional development opportunities in learning strategies on weaving culture teaching in foreign language classrooms at the college-level.

Aydemir and Mede (2014) studied the perceptions and classroom applications of 80 Turkish EFL instructors about integrating the target culture in their classroom. The researchers proceeded through both quantitative and qualitative methods using a questionnaire, semi-structured interviews and stimulated recalls. Results showed positive signs particularly towards the integration of culture in the EFL classroom. Bayyurt (2000) conducted another similar study. She carried out an investigation in 25 EFL classrooms in public and private primary and secondary schools in Istanbul, Turkey. Her aim was to find out the attitudes of non-native EFL teachers towards the cultural aspect of the foreign language they are teaching. The results showed that most teachers were concerned with raising the awareness of their students towards the cultural values of the target language.

\subsection{Students' Attitudes towards the Teaching of the Target Culture}

As far as students' attitudes towards the target culture are concerned, various literatures are available exposing either their positive or negative responses to this notion of integrating a foreign culture into their learning. Lui and Laohawiriyanon (2013) investigated Chinese non-English major students' interest in learning about Big C and small c cultures as well as the sources of culture they favor. A questionnaire was handed to 69 Chinese University students to answer. As far as the cultural themes are concerned, students showed a slightly stronger preference towards Big " $C$ " over little " $c$ " culture. They were also in favor of home culture followed by target culture and intercultural culture. This latter may be attributed to the fact that they were non-English major students, and therefore, do not have much interest in deepening their understanding of the target culture when compared to English major students. Back in 2010, for instance, in relation to students' attitudes towards sources and types of culture, Xiao carried out a survey on the Chinese English-major students and found that they wanted to learn both the target and the source cultures. This is at least a normal expectation from students who are majoring in English, as it is the case presented in this article. Sárdi (2002) surveyed Hungarian university students' attitudes towards specific cultural topics (aesthetic sense, sociological sense, pragmatic sense) of three contexts (target culture context, cross-cultural context, and source culture context) in their EFL courses. It was found firstly that the students were more interested in learning English to improve their career prospects. Secondly, they generally expected a high level of cultural content in their English language classroom. Finally, they wanted to be more exposed to cross cultural issues. In 2010, Jiang carried out a survey to investigate the Chinese students' opinion as to which countries' culture they preferred to learn in their English classroom. A relatively low percentage of students expressed an interest in learning culture i.e. $32 \%$ of them were interested in British cultures, $17.5 \%$ in American culture and $14 \%$ in Chinese culture.

\subsection{Teachers and Students' Attitudes towards the Integration of the Target Culture}

Studies dealing with these two variables at once are very rare in the literature. They all aimed to investigate the following:

- $\quad$ teachers and EFL learners' perspectives on understanding culture

- attitudes towards culture teaching, and the cultural topics they favor to teach/learn in the classroom

- $\quad$ time allocation to culture teaching and learning

- $\quad$ attitudes towards intercultural communicative competence

Kahraman (2016) collected data through a Likert type questionnaire in which both Turkish teachers of English and university students were asked questions to elicit information related to the importance of cultural aspects in learning the target language. The results showed positive signs for changing the perception of cultural teaching by some sound evidence provided by the participants of the study. This study, in particular, is one of the rare research papers that tackles both teachers' and students' 
perceptions towards the target culture inclusion in the EFL class. The gap that has urged us to undertake this research lies in the fact that many research studies have been conducted regarding this topic, yet very few have combined teachers' and students' attitudes towards the teaching of the target culture in the EFL class. With this respect, it is vital to know about the attitudes of both teachers and students towards the target language culture in the EFL class.

\section{Methodology}

\subsection{Data Analysis and Interpretation of the Results}

\subsubsection{Student Questionnaire}

The respondents of the questionnaire were put into categories following their gender and ages as can be seen in the tables below:

Table 2: Students' Gender

\begin{tabular}{|l|l|l|l|}
\hline Male Students & Female Students & Not specified & Total \\
\hline 12 & 40 & 1 & 53 \\
\hline
\end{tabular}

Table 03: Students' Ages

\begin{tabular}{|l|l|l|l|}
\hline From 19 to 22 years old & From 23 to 37 years old & Not specified & Total \\
\hline 38 & 9 & 6 & 53 \\
\hline
\end{tabular}

The respondents were mostly females: 40 females against 12 males with one abstention (Table 01 ). They ranged from 19 to 37 years old. The majority were youngsters, as portrayed in Table 03. Again, 06 respondents did not provide their ages.

\subsubsection{Students' answers to the questionnaire}

\section{Question 1. Answers as exhibited in figure 01.}

I chose to study English (the choice of studying English was my own).

Figure 01: Students' choice of the English language

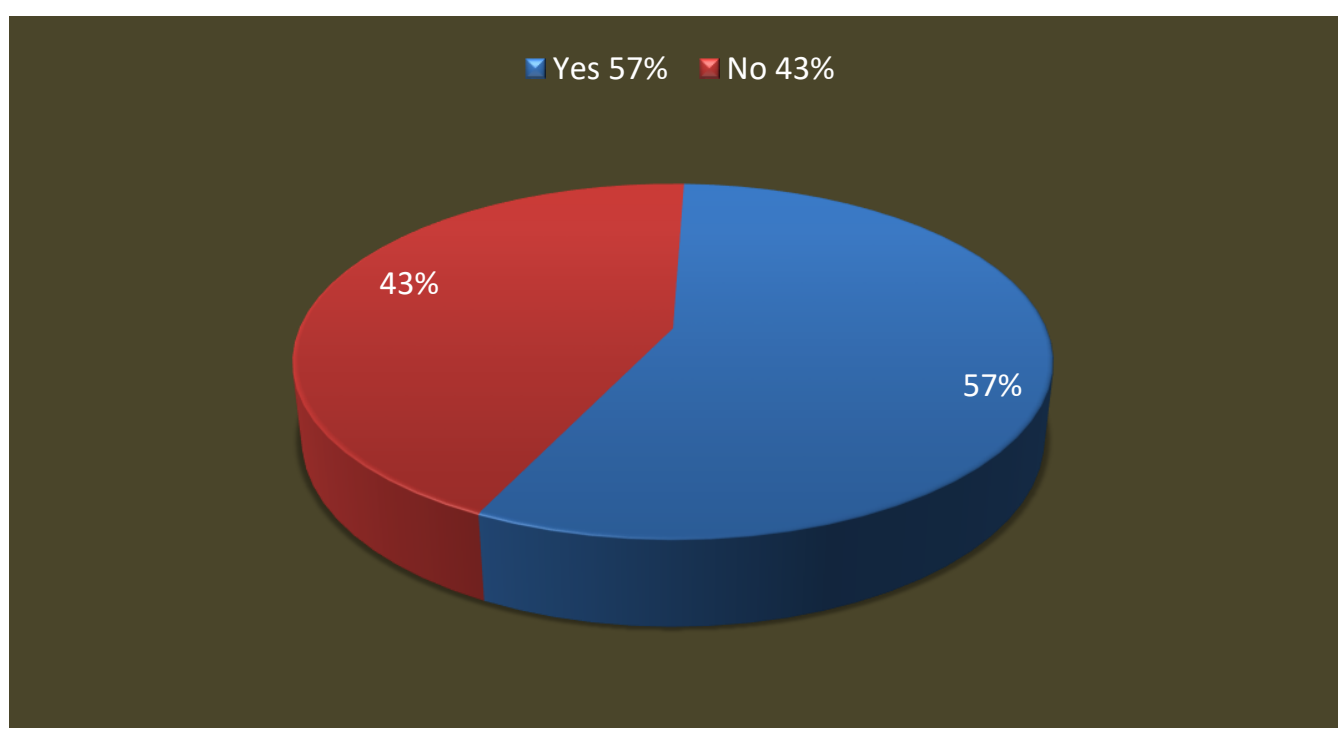

The answers to this question show that learners did not have total control over their choice in studying English, which consequently might have an impact on their attitudes towards the English cultures. 


\section{Question 2}

I am studying English because it is a worldwide language.

Figure 02: Students' awareness of the status of English worldwide

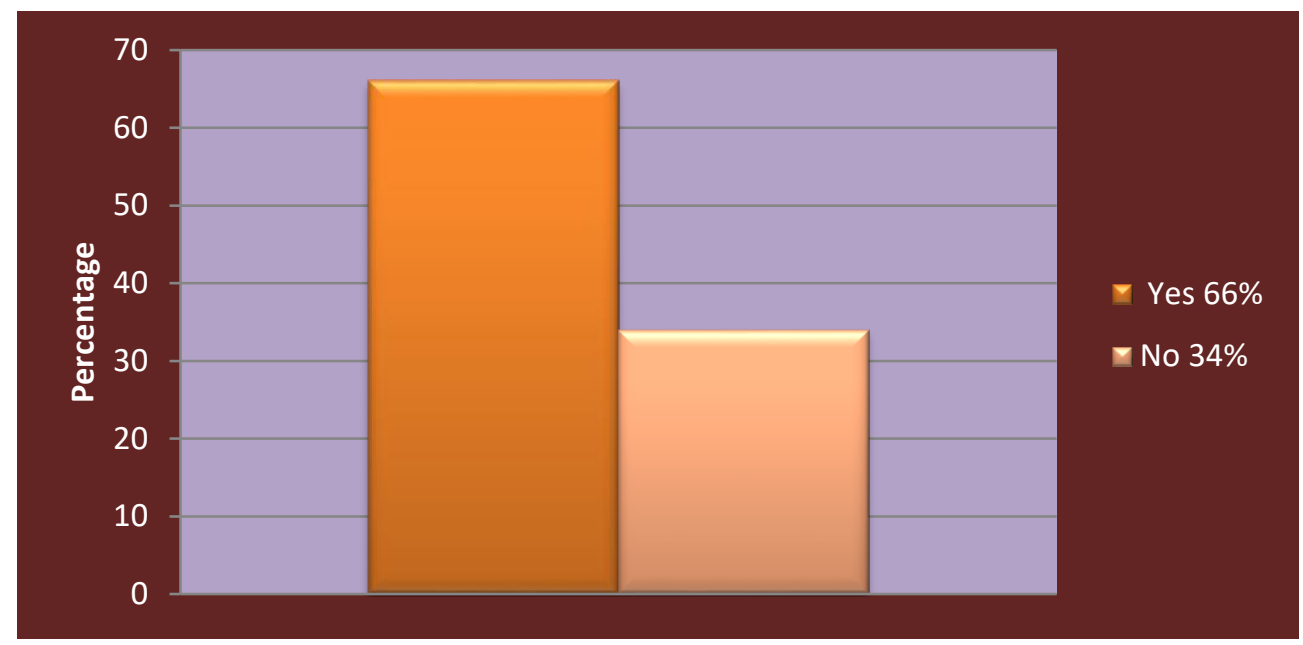

The answer to this question reveals the unawareness of all students of the status of English worldwide.

\section{Question 3}

I am studying English because it enables me to make friends through social media.

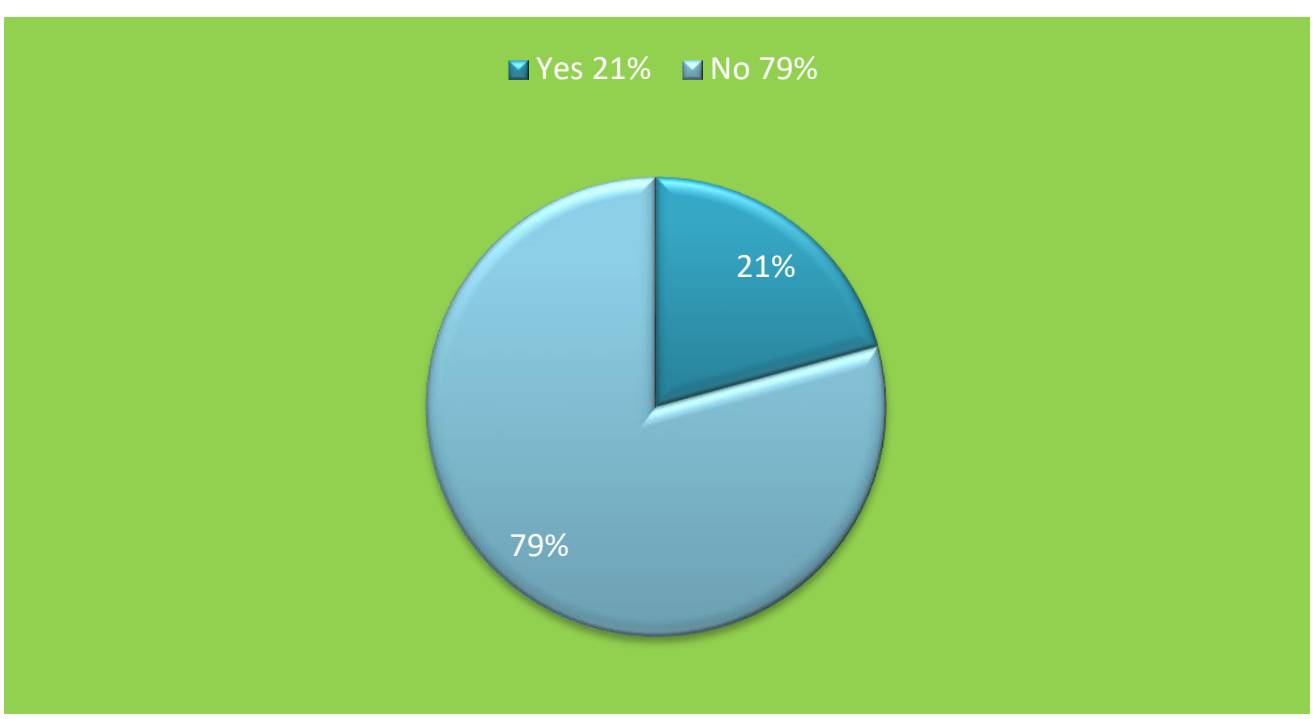

Students who answered with 'No' represented $79.24 \%$ of the population and this denoted their non-use of English through media and the internet to acquire friends from English speaking communities. 


\section{Question 4}

I am studying English because it is socially appreciated to know foreign languages.

Figure 04: The place of English language in Algeria

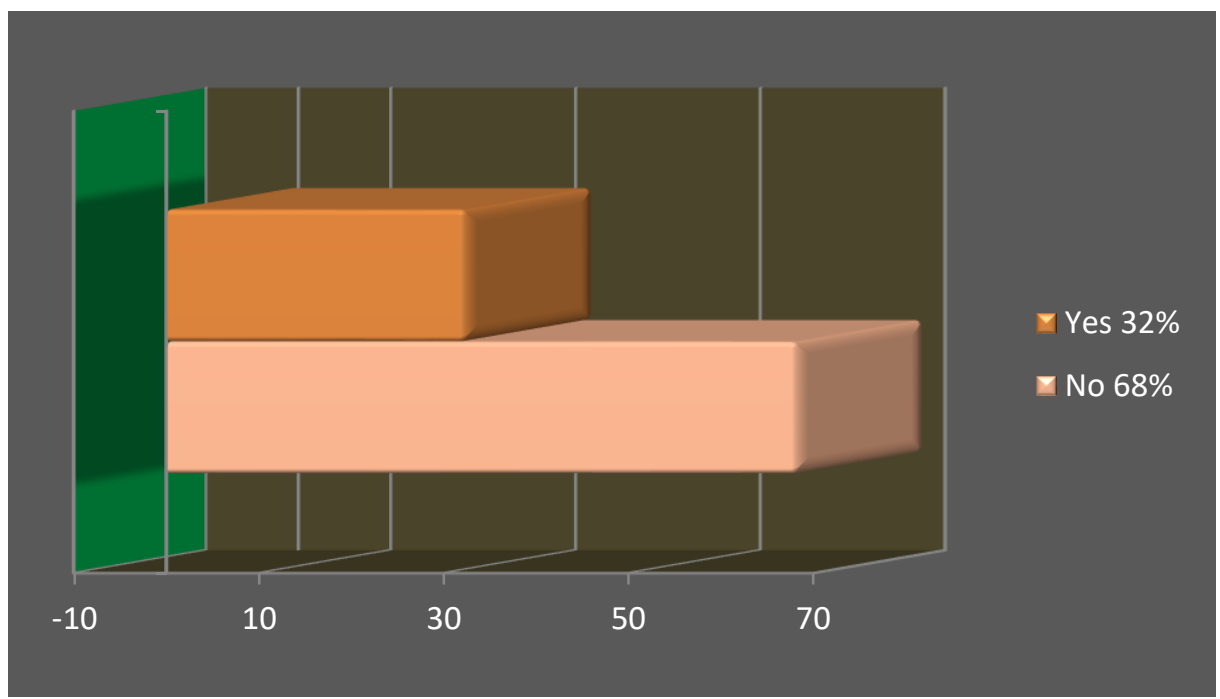

The students provided an unexpected answer to that question as portrayed in Figure 4 with $67.92 \%$ answering 'No'.

\section{Question 5}

5. I'm studying English because it is the language to communicate with all people abroad.

Figure 05: English as a means for international communication

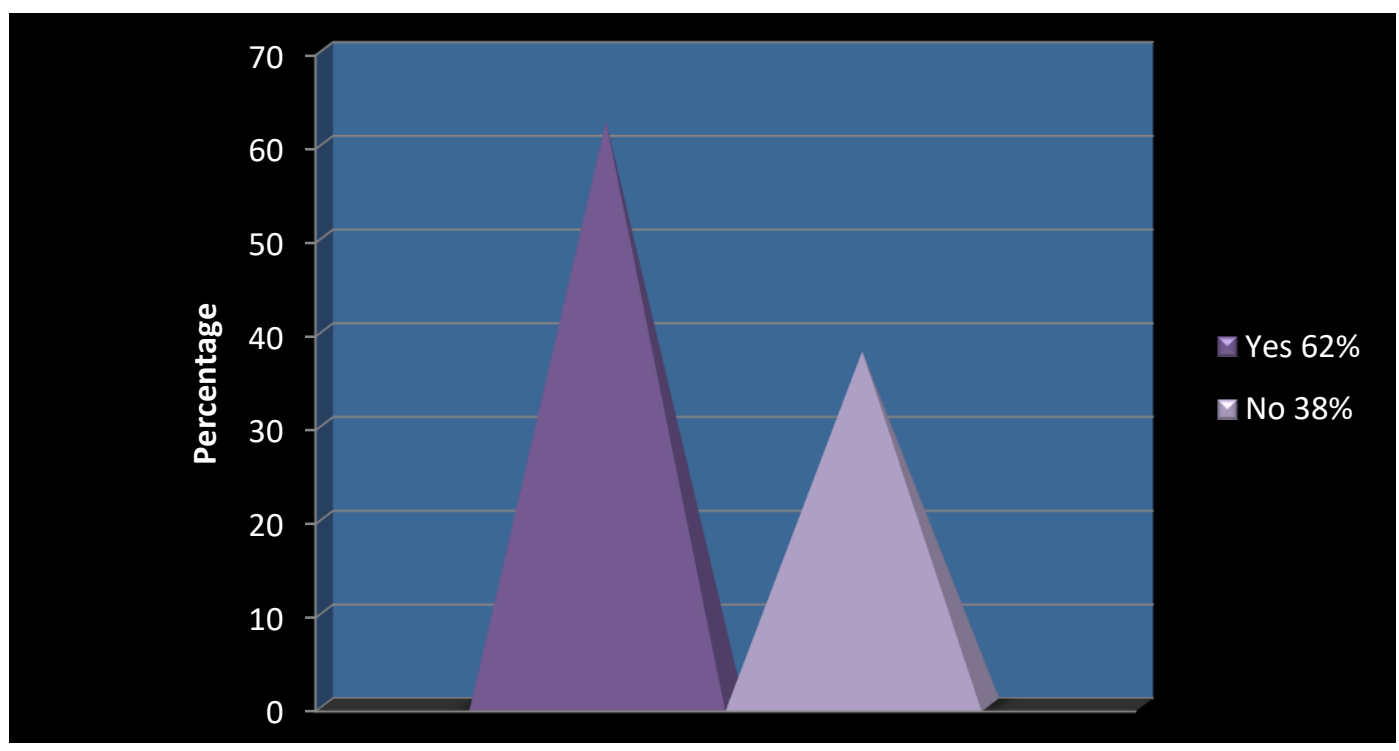

For the sake of cross-checking question 03, students were asked whether studying English would enable them to speak with people abroad. Students(62.26\%) responded positively (see Figure 5). 
Question 6: I am studying English because I want to know about the English culture.

Figure 06; Students' attitudes towards the English culture

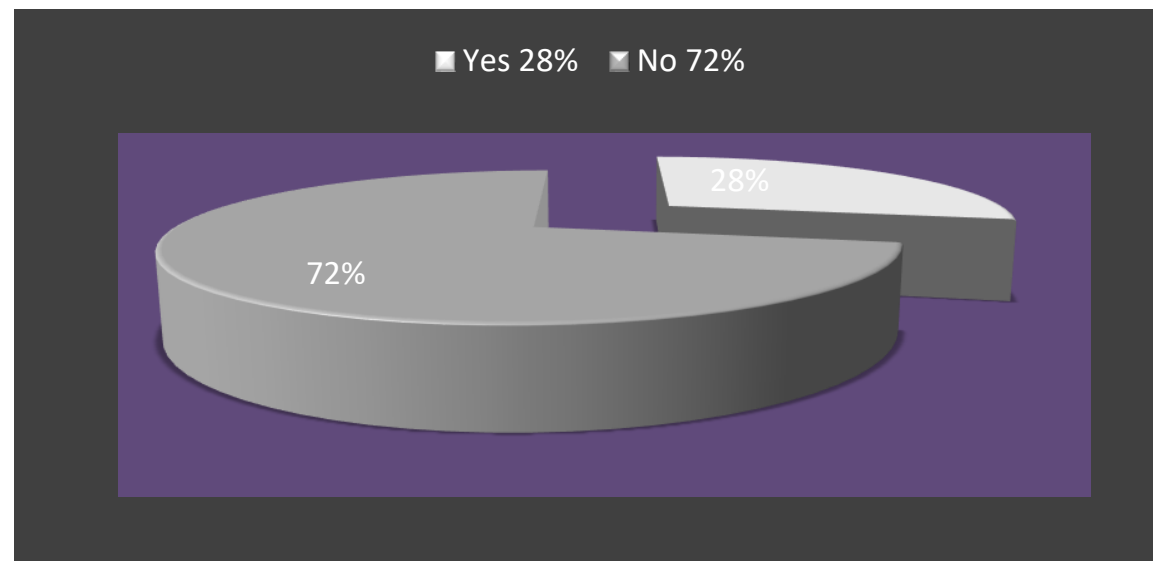

This question is actually at the heart of our research and investigates students' attitudes or perception of the culture of the language they are studying. Actually, students wanted to learn English as such and avoid learning the target culture because of social reasons. Students (71.69\%) gave a negative answer (Figure 06).

Question 7: Knowing the target culture is helpful for Algerian English language students.

Figure 07: Students' perceptions of the target language culture

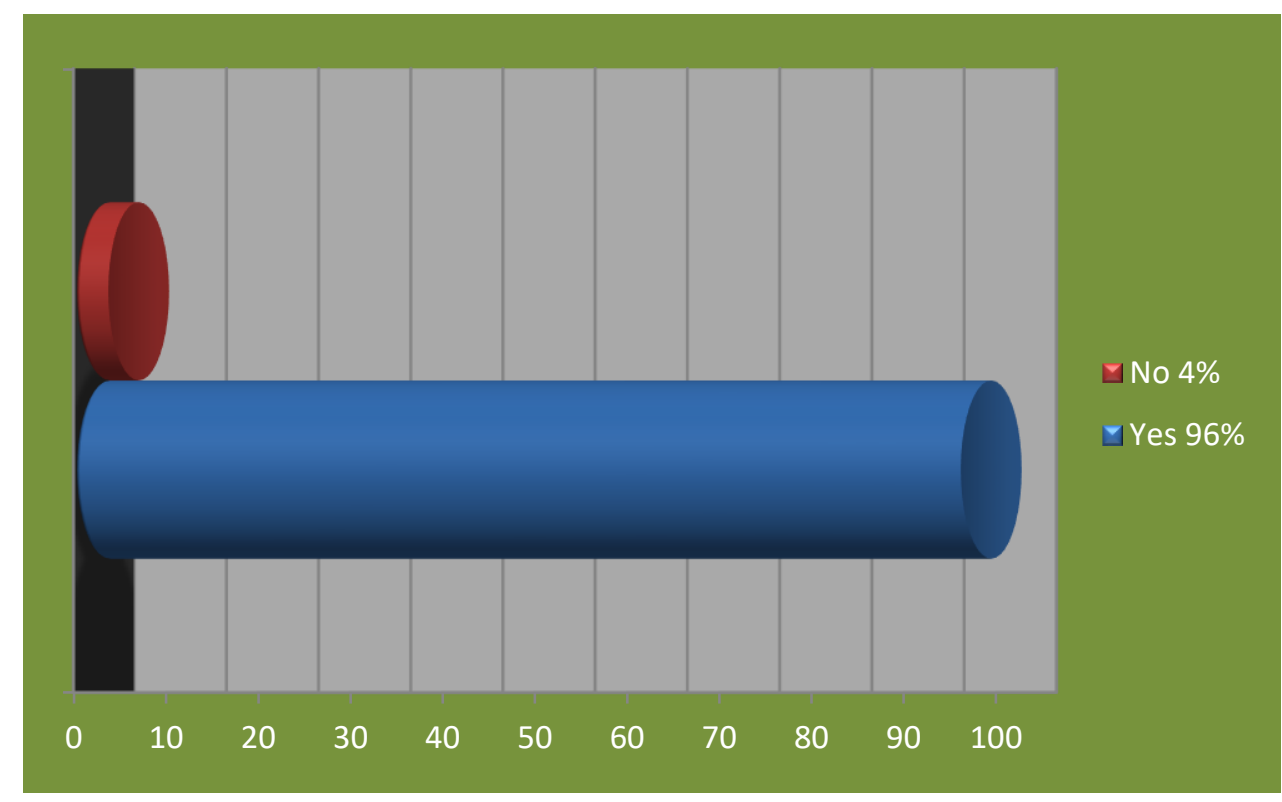

Most students (96\%) agreed that the target culture could be helpful for English learners and thus had to be adequately integrated. This response showed that they were aware of the importance of studying the target culture in the EFL class. 
Question 8: Have you ever studied the target language culture at the university level?

Figure 8: Students' perception about the target culture teaching at Sétif University

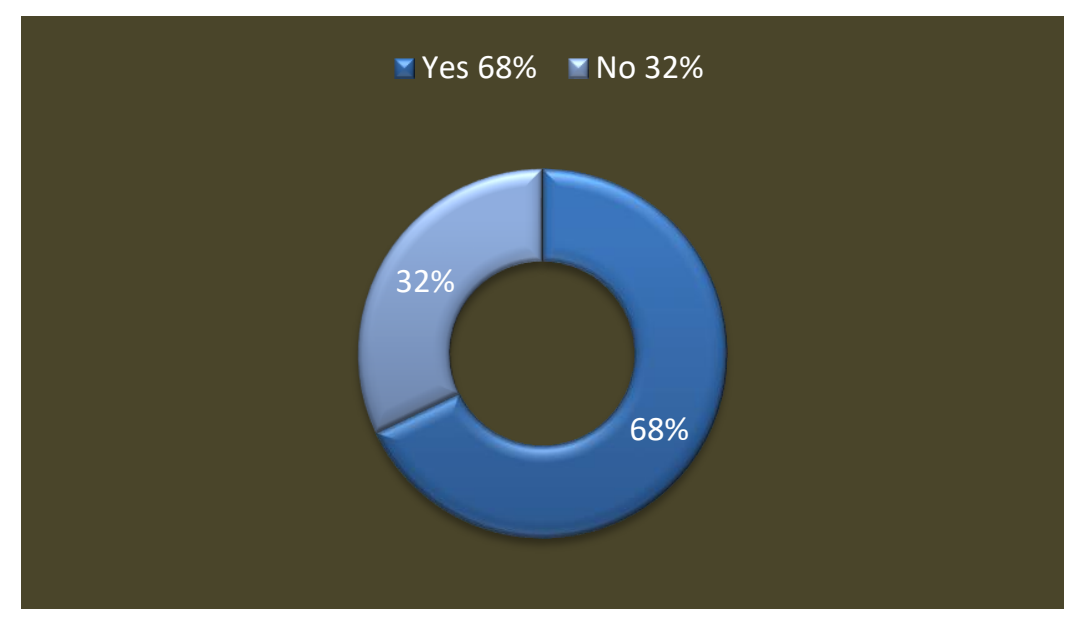

The majority of students, $62.26 \%$,agreed to have studied the target culture at the university, while $37.73 \%$ did not acknowledge they had studied culture. We believe this is because English language culture was taught implicitly and these students wanted it to be overt teaching.

Question 09: Have you ever been taught about the role of body language in the target culture?

Figure 09: Students' perception about body language as part of English culture teaching

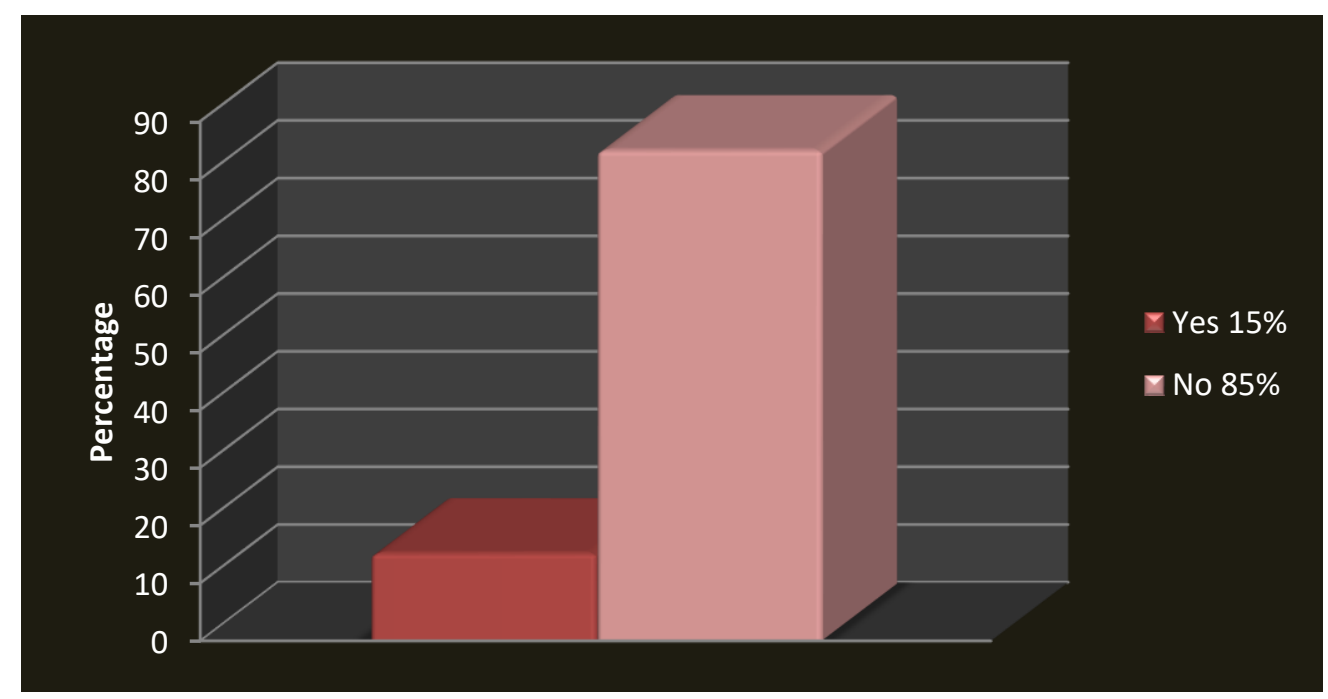

We even sought further to check whether the students are being taught the target culture in their classes. Once again, a high percentage, $84.90 \%$, did not recognize they had been learning about body language. This shows clearly that the teaching of the target culture in class was not been given much importance.

Question 10. Does your religion allow you to open up to the British/American cultures?

This question aimed to check whether religion plays an altering role in students' attitudes towards western culture. As mentioned in figure $15,56.6 \%$ of students pinpointed that they were indeed shaped by their religion that does not permit them to open to the culture of the language they are learning. However, $43 \% .33$ of students found that their religion does not bear any restriction against adhering to other cultures. 
Figure 10: Students' perception about their religion

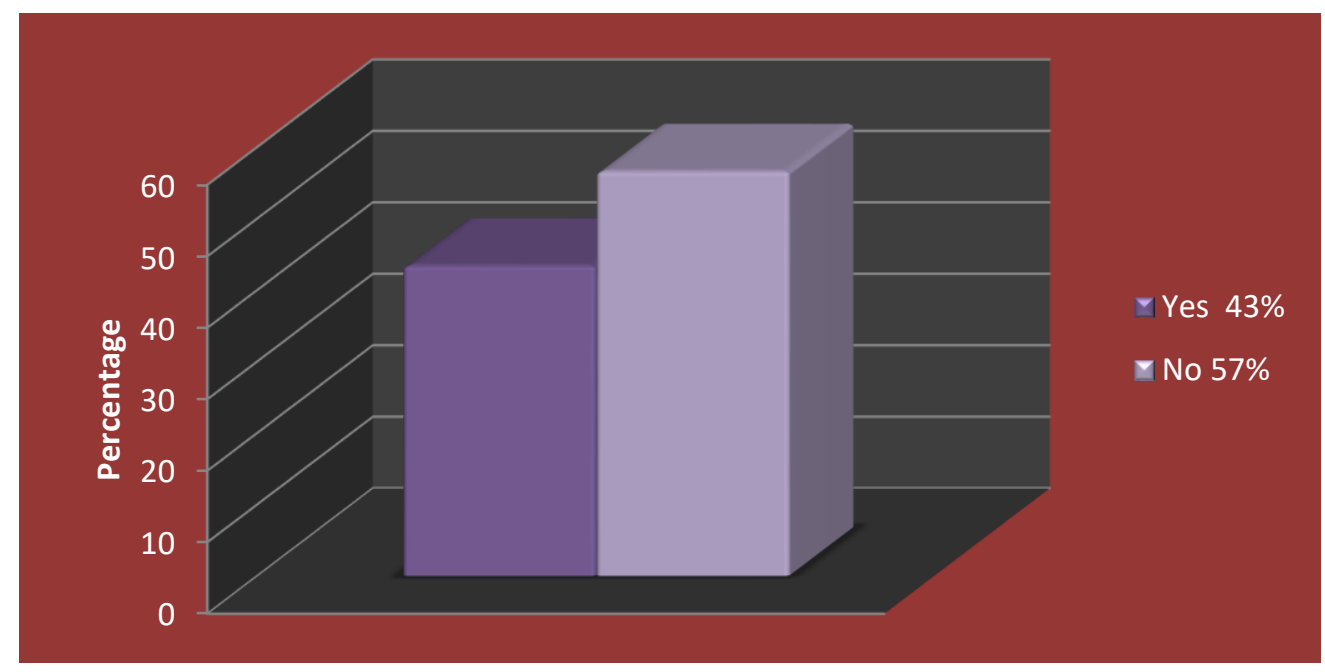

\subsection{Teacher Interviews}

The interview conducted with teachers aimed at shedding light on their attitudes towards the integration of the target culture in the EFL class. The core of the interview was about the following aspects of culture teaching:

1. The complexity of the notion of culture

2. The inseparable relation between language and culture

3. The importance of the target culture in the EFL class

4. Problems of integrating the target culture in the EFL class

5. Techniques and strategies of integrating the target language culture in class.

\section{The Complexity of the Notion of Culture}

Defining culture is never clear-cut. The notion is so complex that giving it a definition is quite difficult and this, because primarily it is used in different contexts. Some scholars define it in terms of membership in a discourse community that shares social commonality (Kramch, 1998). Among our participants, this turns to be the case as they each gave a definition according to the way they perceive the concept. For example, and interviewee said that it has to do with customs, traditions and some beliefs that are related to society and language.

For one participant, it is about people and their identity; it is what makes people different from others. If this teacher sees culture as what differentiates between people, which might not be wrong, some would perceive it as the connection between them. Actually, in trying to find a straightforward definition to culture, one would end up agreeing that it is indeed a complex concept.

\section{The Inseparable Relation between Language and Culture}

There is no doubt that language and culture are interrelated so that no one can deny their inseparability. Some would even go further in their claim by saying that language equals culture and vice-versa. From the different interventions of the participants in this study, teachers have acknowledged this reality. This can be reflected in the following answers. An interviewee mentions that being a foreign culture teacher is not something that language teachers choose. It is embedded in the language. In other terms, foreign language teachers do not choose whether they should teach culture;they teach it anyway. This tends to fit Choudhury and Kakati (2017) comments on the relation between language and culture. For them, language and culture are so connected and inseparable that splitting them will lead to the loss of the essence of each. They emphasize that the connection between language and culture should be interpreted in term of unity. Even if all this seems theoretical than practical especially in a country where little is said about the conceptualization of the target culture, it should be looked at more closely. Another entrusted that: 'Normally, I should integrate the target culture within the EFL class; however, this is only to my limited knowledge'.

\section{The Importance of the Target Culture in the EFL Class}

The importance of the target culture in EFL classes is not a question of debate. The theme has invariably emerged during the different interventions of the teachers. A participant, for instance, said: 'it is very important because as far as learning is concerned, the objective of teachers is to let the students reach two competencies: the linguistic competence and the 
communicative or pragmatic competence. And within the pragmatic competence, culture is the most important'. This statement echoes Kuo and Lai (2006) as described by Choudhury and Kakati (2017). They argue that culture is essential in teaching because it prevents learners from misinterpreting the target language while communicating. Therefore, to converse efficiently, one must not only have the knowledge of the linguistic patterns but more importantly the pragmatic competence that is gained through culture. Similarly, someone else stated that: 'Most of the time, we see or we learn the language from the cultural perspectives. It is not like learning English for Algerians or about the Algerian society, most of the time it is about seeing or using the language in its context. It is authentic; let's say in its context...' This teacher is trying to convey the importance of the target culture alongside the English language. Thus, to gain genuine knowledge of the English language in Algeria, language should be put back in its context and context refers to culture.

\section{Problems of Integrating the Target Culture in the EFL Class}

Stemming from the various interviews, teachers report the sources of problems they encounter while trying to incorporate the target culture in the EFL class. The problems here refer to obstacles, hindrances, difficulties, challenges, lacks etc. To begin with, there seems to be an agreement on the problem of lack of materials among respondents. For example, some participants stated clearly that the difficulties lie in the lack of authentic materials available, which consequently prevents the possibility of bringing the foreign language society, for instance, into the class.

Furthermore, another participant added the issue about curriculum. She revealed that the problem arises because there is an absence of a unified curriculum on culture teaching, and therefore each person teaches according to his or her own perception. Moreover, she evoked problems stemming from students' perception of the target culture as one common challenge that all teachers face. That is, do they accept the target language culture in their class? She further explained that most of the time students link culture to religion and tend to avoid learning anything even the language used in that situation which is against their religion. Stressing this point related to students' attitudes toward different aspects of the target culture, a participant equally commented saying that learners are often shy when talking about themes like sexuality or religion. These are actually Bromley's (1992) words restated in context. It is rather sad that religion should interfere with language teaching because knowing that many conflicts have happened due to the feeling of religious belonging is heartbreaking.

Another challenge signalled by teachers in this study has to do with the limited knowledge teachers have in the target culture due to lack of training. Two respondents actually highlighted this. A participant for example stated: 'I haven't got a prior training, and my target culture knowledge is limited'. Another one added that there is lack of knowledge in the target culture. Interestingly, these two respondents point to this factor even though apparently not existing or neglected by the other teacher. Nevertheless, if teachers are not trained and thus, do not have ample knowledge of the target culture, it constitutes a real barrier to passing it on to their learners. They may fear to misinterpret the norms and values of the target culture society. Added up to other challenges not stated here, there is no doubt that the problems are real.

\section{Techniques and Strategies of Integrating the Target Culture in the EFL Class}

Another emerging theme during the different interventions was the techniques and strategies used by teachers in an attempt to incorporate the target culture within their classes. If there are problems encountered on a way, there are solutions available to overcome them. If teachers are aware of some techniques and strategies to address the problems they face while integrating the target culture, then there is a move forward to achieving the goal of teaching the foreign language. In fact, all interviewees and respondents agreed to having attempted to use some strategies in order to make the classroom atmosphere much like the target language society. A teacher, for example, wrote: 'I try to do this through role play and simulation'. He also added 'When I teach oral expression, I bring authentic conversations and videos to teach them the usage of language in context'. Another interviewee said 'I try to do my best in order to bring the target society into the class, especially through performing plays and some passages from a novel'. Through these different statements, one can gain the understanding that teachers do attempt to use techniques to implement the target culture as far as where their knowledge reaches.

However, one important and basic aspect that they all seem to ignore is raising learners' awareness about the target culture. Thu (2010) believes that "a critical goal of culture teaching in foreign language teaching is to raise students' awareness about the target culture". This was also emphasised by Kahraman (2016) who believed teachers should behave like flag-bearers who have to raise learners' awareness about the dynamic nature of culture. As for the techniques and strategies used by teachers, they are more or less related to Seelye (1981) that include culture capsules, culture clusters, cultural incidents and assimilators, and cultural minidramas for the techniques and authentic materials, lectures for the strategies.

Following the results and discussion of the different themes that emerged from the interviews, the rest of the questions that we asked in the beginning are given full answers. Teachers have shown to be positive about the teaching of the target culture in the 
EFL class. However, for the last question, the findings have revealed that the target culture teaching has not been a focus in the English department of Sétif 2 as shown by the responses of both teachers and students.

\section{Conclusion}

Through the present study, we have attempted to paint an overall picture of the place of target language culture teaching in the Algerian EFL class at the University of Sétif 2. The investigation is conducted with the aim ofxploring teachers and students' attitudes towards the integration of the target culture in the EFL class. Furthermore, we wanted to show that prior to interculturalism and multiculturalism, the mastery of a language requires knowledge at the level of linguistic and communicative competence. The linguistic competence displays the mastery of syntactic, semantic and lexical features that may be very well achieved. By contrast, the communicative competence requires the practical aspect, which is the use of the language in reality. And the key to unlock this communicative competence is the knowledge of the culture of the target culture. The present study has also emphasized the inseparability of language and culture in the process of teaching/learning a foreign language. Therefore, the target culture integration in the EFL class should be welcome openly by both the teachers and the learners. However, because of the big differences between the target and the local cultures, subjects may display negative attitudes towards the target culture rendering this latter a threat for learning to occur. Therefore, students should be armed with ample knowledge about the importance of target culture within their EFL classes so that they may be ready to understand the differences between the local and the target language logics and ready to face the challenges mounting from globalization.

In this attitudinal study, a general idea about the perceptions of teachers and students was portrayed regarding the integration of target culture in the EFL class of Setif 2 University. Results show that teachers are aware of the important role the target culture plays alongside English teaching and are positive towards its integration. This may be explained by the fact that teachers have had enough experience with the English language, and some have even travelled abroad to face situations where the necessity for cultural knowledge was required. Some students' attitudes seem to be ambiguous as portrayed by their answers provided in the questionnaire. On the one hand, they revealed that they are aware of he importance of the target culture for the Algerian English students; on the other hand, they are not happy with the idea of learning about the aspects of the target culture. Interestingly, some students finally conclude that they fear culture shock, which contradicts their religious teachings. This reality may apply to the whole country of Algeria, according to one of our interviewees.

Funding: Please add: "This research received no external funding"

Acknowledgments: In this section you can acknowledge any support given which is not covered by the author contribution or funding sections. This may include administrative and technical support, or donations in kind (e.g., materials used for experiments).

Conflicts of Interest: "The authors declare no conflict of interest."

\section{References}

[1] Al-Amir, B. A. H. (2017). Female Teachers' Perceptions of Teaching Culture in EFL Classrooms at a Saudi University. English Language Teaching, 10(6), 28-36.

[2] Alptekin, C. (1993). Target-language culture in EFL materials. ELT journal, 47(2), 136-143.

[3] Andarab, M. S. (2014). Calling for English for Specific Cultures-based

[4] Coursebooks in English as an International Language Era. International Journal of English Language Education, http://dx.doi.org/10.5296/ijele.v2i2.6619

[5] Archer, C. M. (1986). Culture bump and beyond. In J. M. Valdes (Ed.), Culture bound (pp. 170-178). New York, NY: Cambridge University Press. Atay, D. (2005). Reflections on the cultural dimension of language teaching. Language and Intercultural Communication, 5, $222-236$. doi:10.1080/1470847 0508668897

[6] Ardila-Rey, A. (2008). Language, culture, policy, and standards in teacher preparation: Lessons from research and model practices addressing the needs of CLD children and their teachers. In M. E. Brisk (Ed.), Language, culture, and community in teacher education (pp. 331-351). New York, NY: Lawrence Erlbaum.

[7] Bataineh, R., \&Reshidi, A. E. (2017). The Cultural Gap in EFL Secondary Stage Curricula and Instructional Practices as Perceived bySaudi Students', Teachers' and Supervisors. International Journal of Teaching and Education. DOI: 10.20472/TE.2017.5.2.001

[8] Bayyurt, Y. (2000). Are your students cross-culturally capable?: Teaching of culture in EFL classrooms. In D. Köksal\& I. H. Erten (eds.), Conference Proceedings (pp. 27-30). First International ELT Research Conference. Çanakkale, Turkey.

[9] Bromley, C., M. (1992). Preparing Students for Meaningful Culture Learning. Foreign Language Annals, 25(2), 117-127.

[10] Brdarić, H. (2016). The Importance of Teaching Culture in the Foreign Language Classroom

[11] Brooks, N. (1968). Teaching culture in the foreign language classroom. Foreign Language Annals, 1, 204-217. doi:10.1111/j.19449720.1968.tb00135.x

[12] Brown, H. D. (2007). Principles of language learning and teaching (5th Ed.). New York: Longman.

[13] Byram, M., \&Kramsch, C. (2008). Why is it so difficult to teach language as culture? German Quarterly, 81, 20-34. doi:10.1111/j.17561183.2008.00005.x

[14] Pourakbari, A. A., \&Chalak, A. (2015). Intercultural sensitivity: An empirical study of Iranian EFL learners. International Journal of English Language Education. 3 (2), 1-13. 
[15] Choudhury, M. H. (2013). Teaching culture in EFL: Implications, challenges, and strategies, IOSR Journal of Humanities and Social Science, 13(1), 20-24.

[16] Choudhury, K., \&Kakati, T. (2017). ESL/EFL classroom and culture: An Indian context. Online Proceedings of the International Conference: DRAL 3/19th ESEA 2017

[17] Cortazzi, M., \&Jin, L. (1999). Cultural mirrors: Materials and methods in the EFL classroom. In E. Hinkel (Ed.), Culture in second language teaching and learning (pp. 196-219). Cambridge: Cambridge University Press.

[18] Damen, L. (1987). Culture Learning: The Fifth Dimension in the Language Classroom,

[19] Addison-Wesley Publishing Company.

[20] Fasold, R. (1985). The sociolinguistics of society. Wiley-Blackwell.

[21] Gass, S, M., \&Selinker, L. (2008). Second Language Acquisition. An Introductory Course, Third Edition.

[22] Genc, B., \& Bada, E. (2005). Culture in language learning and teaching. The Reading Matrix, 5 (1): 73-84. Retrieved on June 7, 2014 from: http://www.readingmatrix.com/articles/genc bada/article.pdf

[23] Gonen, S, K.; \&Saglam, S. (2012). Teaching culture in the FL classroom: teachers' perspectives. International Journal of Global Education, $1(3), 26-46$.

[24] Hinkel, E. (1999). Introduction: Culture in research and second language pedagogy. In E. Hinkel (Ed.), Culture in second language teaching and learning (pp. 1-7). Cambridge, UK: Cambridge University Press.

[25] HAN, HUI (2010) An Investigation of Teachers' Perceptions of Culture Teaching in Secondary Schools in Xinjiang, China, [Durham theses[, Durham University. Available at Durham E-Theses Online: http://etheses.dur.ac.uk/109/

[26] Hou, L., \& Lu, Z. (2011). Exploring Cultural Knowledge in EFL Teaching in an EAVSC. Journal of Language Teaching and Research, 2(1), 279283.

[27] Hui, L. (2005) Chinese cultural schema on education: Implications for communication between Chinese students and Australian educators. Issues in Educational Research, 15(1), 17.

[28] Jabeen, F., \& Kazim Shah, S. (2011). The role of culture in ELT: Learners' attitude towards the teaching of target language culture. European Journal of Social Sciences, 23, 604-613. Retrieved from http://www.eurojournals.com/EJ SS 234 10.pdf

[29] Jiang, Y. (2009). On the integration of culture into EFL teaching. Asian Culture and History, 1,144-147. Retrieved from http://www.ccsenet.org/journal/index.php/ach/article/view/3080/2847

[30] Johnson, D. (2005). Teaching culture in adult ESL: Pedagogical and ethical considerations. TESL-EJ, 9. Retrieved from http://teslej.org/ej33/cf.html

[31] Kahraman, A. (2016). Teachers" and Learners" Attitudes towards Culture and Culture Learning in a Turkish Context. Journal of Language and Linguistic Studies, 12(2), 01-12.

[32] Kramer, J. (1994). Cultural studies in English studies: A German perspective. In M. Byram (Ed.), Culture and language learning in higher education (pp. 27-43). Bristol, PA: Multilingual Matters.

[33] Kramsch, C. (1993). Context and Culture in Language Teaching. Oxford University Press

[34] Kramsch, C. (1998). Language and culture. Oxford, UK: Oxford University Press.

[35] Kramsch, C. J. (2008). Language and culture (8th ed.). (H.G.Widdowson, Ed.) Oxford University Press.

[36] Lado, R. (1986). How to compare two cultures. In J. M. Valdes (Ed.), Culture bound: Bridging the cultural gap in language teaching (pp. 5263). Cambridge: Cambridge University Press.

[37] Lange, D. L. (1998). The Teaching of Culture in Foreign Language Courses. Center for International Education (ED), Washington, DC.

[38] Lange, D. L., \& Paige, R. M. (2003). Culture as the Core Perspectives on the Culture in Second Language Learning, Information

[39] Age Publishing.

[40] Lonf-Fu, X. (2001). Teaching English Cultural Background: Introducing the Target Culture into the Chinese Secondary School English Classes. ISBN 951-44-34-5

[41] Liu, S., \&Laohawiriyann, C. (2012). Cultural Content in EFL Listening and Speaking Textbooks for Chinese University Students. International Journal of English Language Education. URL: http://dx.doi.org/10.5296/ijele.v1i1.2850

[42] Liu, S., \&Laohawiriyanon, C. (2013). Students' Attitudes towards Cultural Learning in the English Classroom: A Case Study of Non-English Major Students in a Chinese University. International Journal of English Language Education. URL: http://dx.doi.org/10.5296/ijele.v1i3.3508

[43] Nadia, R. (2015). The Leaners' Educational and Cultural Background Effect on their Proficiency in Learning English. Doctorat Es-Sciences in Foreign Language Teaching.

[44] Oppenheim, A. N. (1992). Questionnaire Design, Interviewing and Attitude Measurement NY

[45] Paige, R. M.; Jorstad, H.; Siaya, L.; Klein F. \& Colby J. (2003). Culture learning in language education: A review of the literature. In

[46] D. L. Paige (Ed.), Culture as the Core: Perspectives on Culture in Second Language Learning. IAP.

[47] Peterson, B. (2004). Cultural intelligence: A guide to working with people from other cultures. Yarmouth, ME: Intercultural Press.

[48] Podromou, L. (1992). What culture? Which culture? Cross-cultural factors in language learning.ELT Journal, 46, 39-50. doi:10.1093/elt/46.1.39

[49] Programme d'Anglais Deuxième Langue Etrangère, Algérie (2006). Direction de l'Enseignement Secondaire, Commission Nationale des Programmes.

[50] Sárdi, C. (2002). On the Relationship between Culture and ELT Studies about Languages.

[51] Volume 3, 101-107.

[52] Sarıçoban, A., \& Çalışkan, G. (2011). The influence of target culture on language learners. Journal of Language and Linguistic Studies, 7(1). Retrieved on June 7, 2014 from http://www.jlls.org/index.php/jlls/article/view/101/101

[53] Scheu, D. (1996). Integrating Cultural Activities in the Foreign Language Classroom.

[54] Shin, J., Eslami, Z. R., \& Chen, W. C (2011). Presentation of local and international English-language teaching texbooks. Language Culture and Curriculum. (pp. 253-268) 24 (3). Routledge. 
[55] Tang, L. (1983). TEFL in China: methods and Techniques. Shanghai, Shanghai Foreign

[56] Languages Press.

[57] Tang, R. (1999). The place of "culture" in the foreign language classroom: A reflection. The Internet TESL Journal, 8. Retrieved from http://iteslj.org/Articl es/Tang

[58] Thanasoulas, D. (2001). The importance of teaching culture in the foreign language classroom. RadicalPedagogy.Retrieved from http://radicalpedagogy. icaap.org/content/issue3_3/7-thanasoulas.html

[59] Thomas, J. (1983). Cross-cultural pragmatic failure. Applied Linguistics, 4(2), 91-109.

[60] Thu, T, H. (2010). Teaching Culture in the EFL/ESL Classroom. Alliant International University. San Diego, California

[61] Trinovitch, G, J. (1980), Culture Learning and Culture Teaching. In Croft, K. "Reading of English as a Second Language".

[62] Cambridge, Mass: Winthrop Publisher, Inc

[63] Xiao, J. (2010). Cultural contents of an in-use EFL textbook and English Major Students' Attitudes and Perceptions toward Culture Learning at Jiangxi University of Science and Technology, China. Unpublished master's thesis, Prince of Songkla University, Songkhla, Thailand.

[64] Yang, X., \& Chen, D. (2016). Two barriers to teaching culture in foreign language classroom. Theory and Practice in Language Studies, 6(5), 1128.

[65] Yeganeh, M. T., Raeesi, H. (2014). Developing Cultural Awareness in EFL Classrooms at Secondary School Level in an Iranian Educational Context.Procedia - Social and Behavioral Sciences 192 (2015) $534-542$ 